\title{
Time-Budgets: A Tool for Evaluating Liveable Urban Planning in Smart Cities
}

\author{
Philippe DUEZ ${ }^{1}$ \\ Ioan RADU 2 \\ Alexandra Irina $B A D E A^{3}$ \\ Mihai Ludovic DEMETER ${ }^{4}$
}

\begin{abstract}
It is said that time means money. But, in a world where time seems to be compressed, finding the time to complete all daily tasks and finding a balance between personal and professional life is becoming increasingly difficult. Even more, we live in a world of gadgets and devices that are meant to make our life easier, and more manageable and utilising smart tools and living in a smart city seems to be parts of the solution, if not THE solution. The equilibrium between personal and professional, with all the aspects that these two imply, makes a city more liveable in respect with others that may not offer the same opportunities, the same interest form the public administration sector to make the city appealing and use all the tools of smart urban planning to achieve this goal. Based on the bibliographic analysis in the field, using the method of fundamental research of materials retrieved from Scopus, Web of Science and Science Direct database, this article aims to take a step in showing that time budgets can become a viable assessment tool for quality of life in smart cities.
\end{abstract}

KEYWORDS: smart city, smart tools, urban planning, time-budgets.

JEL CLASSIFICATION: $R 58, Q 01, O 21$

\section{INTRODUCTION}

Rising demands in terms of sustainable development are the basis of changes in land use planning policies (Lacour et al., 2008). They become the privileged tool for applying the precautionary principle in the search for each of the three pillars. In France, urban planning dates back to the 1960s, but it has been formalized and above all turned towards sustainable development since the beginning of the 2000s (Douay, 2013). Because they are precisely more structural, these public policies do not escape the evaluation logic that results from the application of the principles of "Post New Public management" and the integrated impact study of such decisions (Hammerschmid et al., 2019) and (Marchand \& Brunet, 2019). The first logic implies that we have an evaluation tool that will allow monitoring of the effects of urban planning on the economic level but also on the level of sustainable development. The second implies that one can assess the impact of a public decision before implementing it. Having a tool allowing this double assessment seems particularly necessary when we are targeting the liveable aspect of urban development which combines the ecological and the social.

\footnotetext{
${ }^{1}$ University of Artois and UMR CNRS 9221, France, philippe.duez@univ-artois.fr

2 Bucharest University of Economic Studies, Romania, iradu13@gmail.com

${ }^{3}$ Bucharest University of Economic Studies, Romania and the University of Artois, France, ib alexa@yahoo.com (corresponding author)

${ }^{4}$ Bucharest University of Economic Studies, Romania and the University of Artois, France, mihaidemeter2004@ gmail.com
} 
This article aims to show that time budgets can become this liveable assessment tool. It is part of a research program funded by Europe on the evaluation of the quality of public services in Romania and in the framework of a thesis co-supervision in economics and spatial planning and town planning. Using mainly the method of fundamental research, analyzing the specialized works in the field, we will present the framework in the first part, returning in particular to the temporality of the urban world. The conclusions were formulated based on basic research, using specialized materials (books and articles) published between 1960-2020, selected from the Scopus, Science Direct and Web of Science databases, based on search criteria that used the terms or combination of terms: time, time management, urban planning, smart city, temporal policies and/or urban lab, both in abstracts and in the text of the documentary material. The development of time policies since the beginning of the $2000 \mathrm{~s}$ is increasingly important. In our opinion, it foreshadows that an urban planning policy should respond to certain problems of the liveable. We will present these temporal policies in a second part, emphasizing in particular the place that could be attributed to the "smart city" approach in this planning. Their development notably involves the implementation of time offices in the cities. The subject matter dealt with there is quite particular knowing that time is a fact that can neither be spared nor increased. It is easy to imagine the dialogue that the little prince could have when he addresses the official of one of these offices, saying to him: "please give me time". The use of a method that makes it possible to objectify it and give substance to this mission would be all the more useful than those that exist because they are often unused (Mallet, 2014). We will therefore show in a third part that the time-budget method can be adapted to be very useful for evaluating the activity of a time office and therefore of urban planning based on the liveable.

\section{THE IMPLEMENTATION OF A TEMPORAL ECOLOGY. A NECESSITY FOR THE URBAN WORLD}

To satisfy their need to exist, whether on a material level (food, accommodation, travel for example) or their search for identity within society (culture, relax, meet other people), individuals will choose a "topochrony" (Ferrier, 1998). Of course, not all companies have the same vision of this report and the same "topochrony". It depends first of all on the choices they make in terms of the work process and production (Dupuy, 2001). Societies will evolve from a hands-on hold in nature and with few resources to the use of increasingly artificial capital to meet increasingly important material needs (Testart, 2012). They will increasingly use the market and the logic of constitutional government to distribute the wealth that they will produce (Polanyi, 1988). Today the temporality is guided by a technico-economic and scientific temporality (Hottois, 1990) Anthropo-theological temporality implies a symbolic regulation of society where society takes precedence over the individual (Freitag, 2002). The techno-economic and scientific temporality is that of human activity oriented towards reflexivity and towards progress without ethical limits. In this temporality the history of humanity boils down to the progress of the human spirit applied to the human spirit, and of the human spirit applied to history (Guibert-Sledziewski, 1988). There is therefore a difference in "topochrony" between what we will qualify as traditional and modern societies. (Forget \& Polycarpe, 1990).

In traditional societies the choices in terms of "topochrony" are constrained by the space-time relationship arising from nature. Man is the victim of symbolic regulation and a power which obliges him to incorporate social norms and accept his fate without asking any questions (Gauchet, 1998). In modern societies we seek to free ourselves more and more from spatialtemporal constraints in order to have a "topochrony" that allows activities, places and links to 
be changed as desired (Ascher, 2003). The regulation of the activities of society takes place on the basis of a functional division to which corresponds a functional division of the human mind (Freitag, 2002). Time becomes more and more spatialized and less and less becoming (Zarifian, 2003). Modern man spends more and more time on intermediate activities which do not necessarily make sense in them (Arendt, 1983). He will really have the impression that his life is accelerating, that he is running after time and experiencing the temporal depression of a time that has no meaning and that he cannot spare (Rosa, 2010).

Urban times are more and more complex. They are strongly differentiated, no longer linear, because changing lifestyles and new technologies allow interactions to make these times individual and collective at the same time. The time of hyper spatial is indeed more and more out of sync with the rhythm of nature, our biological rhythm and especially our needs for existential affirmation. The race for time is in fact only a race for money, don't we say that "time is money" when it is anything but that. After the era of relaxation comes the era of hardening times associated with hyperconsumption or the hell of things (Dumouchel \& Dupuy, 1979; Lipovetsky, 2004). This race is paradoxical. "It is enough that some continue the game of the absurd for others to do the same, for fear of being left behind, even though all collectively, we would have an interest in stop, in ensuring that productivity gains are at least partially converted into temporal resources" (de Montbrial, 1985).

In such a context, it is appropriate to make the proposal of a temporal ecology. First of all, if we aim for the liveable, this ecology is first of all integral. It is therefore necessary to avoid impoverishing the temporal equation by seeking to free one completely from spatio-temporal constraints because this "delivers people to indeterminacy and almost to psychic and motor paralysis, to the total absence of any investment of their proven person in anything. This results in discomfort, pain in life and bad conscience." (Grossin, 1996). The activity of consuming water is biologically necessary for humans, but it can result in more or less important or restrictive social or personal times. This is what the famous dialogue between the little prince of Saint-Exupéry and the merchant expresses when he says that if he had the time he would devote it to walking slowly towards a fountain rather than earning the money that would allow him to buy the anti-thirst pills. Water consumption therefore refers to a work process which involves a different temporal equation.

Grossin (1996) emphasizes the importance of personal time to avoid imbalances with social time and its effects on personality deterioration. He points out the important role played by the family in increasing the quality of life, saying, "The family represents for temporal ecology a breeding ground. [He suggests temporal arrangements] capable of reducing tensions, of modifying endured situations, wrongly judged inevitable" (Grossin, 1996). It is "a time when you have to choose between what you keep (for continuity), what you throw away and what you reinterpret (for change)" (Micoud, 2005). To avoid the impoverishment of the temporal equation, the hyper spatial will have to re-regulate its existence by changing its existential affirmation modalities (Arnsperger, 2010). The evocation of change is beyond the scope of this article, however, since it presupposes a new economic ethic. On the other hand, we can focus in the second part on planning policies that will make it possible to concretely transform this temporal equation. 


\section{THE PLACE OF TEMPORAL POLICIES AND "SMART CITIES" IN THE URBAN PLANNING OF THE LIVEABLE}

Urban planning consists in imagining or "re-imagining" an urban space at spatial scales and / or for different projects and in coordinating public policies and private projects implemented to meet economic or sustainable development objectives (Douay, 2013). Urban planning, however, remains rather spatial and not temporal. The question of urban rhythms of life and their more or less liveable character is therefore more difficult to ask than the other two pillars. Time policies will seek to fill this gap. "Time policies integrate new management methods into urban planning, while planning documents question land use, excluding management issues. However, the link between these two practices is essential" (Beyer \& Royoux, 2015). The downside comes from the fact that local authorities, with a few exceptions such as Poitiers or Rennes, which participated from the start in the experiments, will not support this type of policy (Royoux, 2017). From then on, time policies will develop in a "bottom up" manner. They will be part of a renewal of urban policies that adhere to a constructivist and less rational-global approach to planning (Douay, 2013). The temporal policies are first of all supported by Europe within the "equal" program on gender inequalities in urban times and the Eurexter program which aim to develop democracy through the exchange of good practices in European public policy. (Dommergues \& Delfour, 2001). The "Tempo Territorial" association created in 2004 will take over from Europe for the exchange of good practices and lobby for this type of policy to be taken into account. This gave rise to the report by deputy-mayor E. Hervé who, like Italy, called for the creation of time offices in France for towns with more than 20,000 inhabitants. Time policies will be divided into two categories of proposals.

The first category concerns the reduction of temporal gender inequalities. Studies on the temporality of women show they are particularly disadvantaged by the setting aside for men and not for them of the personal time devoted to the house maintenance, the childrens' education or the time spent in connection with the family management such as school, shopping etc. (Boulin, 2003). When they have a professional activity their life rhythm seems more accelerated. They are therefore more exposed to the "burn out" risk. They also have less access to more skilled jobs or more distant from their homes. The second category of proposals revolves around actions that seek to reverse the logic of development by recomposing the time-space links based on changes in temporality. These will lead to the implementation of a city's malleability, its fluidity for development and mobility which will guarantee accessibility and connection to different networks. They will promote the flexibility of equipment and the heterotopia that accompanies it (Beyer \& Royoux, 2015; Lucchini, 2015).

The limits of temporal policies lie in our opinion in the difficulties they encounter in giving themselves a societal ambition such as improving the quality of life. This deficit is understandable given the complexity of today's urban temporality. On the other hand, geographers and planners whose job it is to observe and try to decipher, space will not be a victim (Berque, 2009). This could explain, for example, that by developing flexible working hours, we end up requiring a territorial temporality of the 24/7 type (Boulin, 2003). But the risk is to forget the systemic nature of inequalities.

It must be said that the introduction of ethical issues into spatial planning policies is not easy either. This refers to what in a geographic contract constitutes the way of seeing our destiny, to what invisibly regulates our way of geographizing the world (Ferrier, 1998). It is a way that 
humans use to extend their influence over the world and to inhabit it with other human beings. We can associate with it three principles that will allow us to locate the ethical deficit: the principle of hominization, anthropization and humanization (Berque, 2009). Anthropization refers to the way in which man influences nature to meet his needs by using more or less technique. This raises the question of the economy in the broad sense including the labour process and the resulting land use planning. Hominization locates man's place in nature according to the biophysical conditions of his appearance. This allows us to say that he is responsible for the impact he has on nature given his privileged position as Homo-Sapiens. $\mathrm{He}$ is responsible in the sense of $\mathrm{H}$. Jonas vis-à-vis future generations of what he puts him through in the perspective of sustainable development (Burbage, 2013).

The ethical difficulty comes above all from the definition of the principle of humanization, especially since the Larousse does not help us when he says that he is human, which refers to the characteristics of the human species. So let's try to identify these characteristics to see where the ethical deficit of temporal policies lies. The first of the characteristics is that any stable human society is based on "the existence of an institutional framework and of a regulatory power capable of arbitrating the conflicts which arise at any time, when it comes to of the appropriation and allocation of scarce resources" (Furtado, 1987). This has come at the cost of political revolutions that have brought about the famous constitutional government of Polanyi which gives the state a monopoly on violence and trusts the market to produce and distribute resources so as to meet the needs of the humanity. The problem is that "a selfadjusting market could not exist without destroying all human substance and turning our environment into a desert" (Polanyi, 1988). There is therefore a loss of human substance when there are still totally unjustified problems of distribution of resources. The second characteristic is that any stable society is based on a principle of "universion" which leads each individual to seek in his existential affirmation what is common in all humanity (Berque, 2009). The problem is that in this research man is the subject-object of his own development, in other words his conception of himself via the principle of hominization. By insisting too much on the anthropo-theological aspect of temporality and on the symbolic regulation of society which results from it, certain individuals have been considered as animals without any rights while humanity must accept to put its destiny back between hands of gurus and other shamans or accept their fate in the face of events that they cannot explain.

Conversely, by insisting too much on the technic, economic and scientific dimension and the functional regulation of society we risk forgetting society in favour of an individual who will have only rights (Freitag, 2002). We are therefore in the presence of a personality of the third type capable of making social standards more flexible (Gauchet, 1998). We can then speak of the obsolescence of man, of a "post-human" or of a superman becoming totally subject to his own development, in other words of a "man-God" (Vergely, 2015). If we take a critical perspective of over-modernity, we will defend the idea that the impoverishment of the temporal equation of the two series of propositions can come from the fact that they have too much confidence in the second form of temporality. The application of the precautionary principle in matters of liveable becomes difficult knowing that the age of precaution is that of doubt about current knowledge (November, 2002).

The proposals concerning the regulation of territorial time put too much emphasis on the problems of gender inequalities. This will not impoverish the temporal equation because urban temporality offers a hectic and exciting life allowing access to an expanded sociability (Ascher, 1995). Individual freedom of choice will increase while coexisting with a collective mechanism of experience sharing and cooperation so that at the same time it will guarantee 
the stability of society and the psychic balance of individuals. On the contrary, by pushing too far the functional division of activities and the search for mobility we will harden urban temporality and make the city less and less liveable. This is what the first town planners predicted. It is this same confidence that has plunged the report on the liveable of the club of Rome (Giarini, 1981) into oblivion. Two ways of impoverishing the time equation can follow. Impoverishment can come from the illusion of thinking that there is no hardening of working time because it is less and less important. We can see that it is reduced since it only represents $12 \%$ of a lifetime (Beyer \& Royoux, 2015). Yet it hardens because it keeps personal time more and more on the margins. However, this is what happens when we leave the question of personal time in the private sphere in the name of individual freedom (Boulin \& Mückenberger, 2002). Time pressure at work is stronger than ever as it causes the development of "burn out". Time pressure on personal time has never been greater. In order to exist in the new spirit of capitalism, the company becomes the place par excellence where one will realize oneself and be creative, which means that everything that is done outside loses its interest (Boltanski \& Chiapello, 1999). We continue to discredit personal domestic time or the time spent volunteering by considering that it is not a real job; "a woman has no job when she devotes her time to raising her own children; and that she has a job when she devotes even a fraction of her time to raising the children of others in a nursery" (Gorz, 1997). In addition, the digital economy increasingly associates personal time with working time. This is the case when, in order to work, we have to become a consumer-entrepreneur, in other words everything we consume makes us more efficient in our work (Rochefort, 1997). This is the case when we learn in our personal temporality to have access to what in the future will be comodified (Rifkin, 2000). To enrich the temporal equation, it will ultimately be necessary to focus on the changes in the work process, which requires a different economic ethic.

Impoverishment can come from the illusion of thinking that the recomposition of space from territorial times is not going to be a problem. On the contrary, we note that this risk being reflected in a multiplication of the number of non-places (Augé, 1992). Non-places are places that produce little emotion since you are plugged into them and where relationships based on co-presence are of no interest. They are affectively neutral. They are built on the basis of a glass and concrete architecture to make them more functional, therefore have no anthropological depth serving intermediate activities requiring mobility or places associated with work or consumption such as stations, airports, large bars in the suburbs.

The depletion of personal time must be linked to the risk of producing a "schizotopia" in space (Anders, 2011). The underlying idea is that we are good everywhere because we feel "at home" everywhere since we are familiar to everyone thanks to new technologies. They give us the opportunity to come into contact with appearances of friends who are not "real people" (Anders, 2002). At the same time, we are witnessing a "de-privatization" of "home" which leads to the deconstruction of all the intimacy that human beings nevertheless need in order to have emotional security. Indeed "the sign that we are at home is that we manage to make ourselves understood without too many problems, and that at the same time we succeed in entering into the reasons of our interlocutors without needing long explanations" (Augé, 1992). It therefore allows psychic discharge (Di Méo, 1991). The impoverishment of territorial time must be linked to the forgetting of the principles of spatial anthropology of building and heritage. The edification of any construction meets two objectives (Choay, 2006). Leave to future generations the mark of its passage while symbolically reflecting through architectural work the expression of its power and grandeur. This is why building materials are chosen to last over time. He therefore patrimonializes space and gives it 
meaning in order to be able to stabilize or re-stabilize its relationship to the world when it is deconstructed (Gravari-Barbas \& Violier, 2003).

The concept of "smart city" is, like that of time policies, an imported and "bottom up" concept, but their origin and objectives are different. It has an Anglo-Saxon origin and spread quickly in Europe which supported its development through the financing of certain projects. There is, however, a shift towards Asia (Henriot et al., 2018). The translation even into a smart city of the Anglo-Saxon term, which largely explains its success, poses a problem (Eveno, 2018). What intelligence are we talking about? Real intelligence of the humans who inhabit it or artificial intelligence that can be associated with the technological innovations that develop there, like temporal policies, related urban planning actions suffer from a deficit of "geographicity" and an ethical deficit.

Smart cities are based on the use of data that new technologies make it possible to collect and process to achieve ecological objectives, fluid and malleable city that promote the management of all flows. The Japanese who highlight this aspect have also preferred the term "smart community" rather than "smart city" (Henriot et al., 2018). These characteristics and these objectives fully correspond to the definition given by the European Parliament in 2014: "a smart city is a city seeking to address public issues via ICT-based solutions on the basis of a multi-stakeholder, municipally based partnership" (taken up by (Chopplet, 2018).

Time is a flow since it can neither be saved nor increased, but can be used to recompose territorial time into personal time to ensure the latter is less marginalized. It can be seen as an invasion of personal life through work if work at home continues to be stigmatized (Planterose, 2014). The vision of the city that underlies it refers to the same ethical deficits and the same risks of impoverishment of the temporal equation.

The production of "big data" which makes it possible to regulate territorial time to put less marginality on personal time also takes time and introduces new inequalities between those who master the tools and will have easier access to time and the others. Moreover, smart technologies could be liberticidal if collective self-consumption resulting from regulation by "big data" increases the influence of collective time on personal time. The web then becomes the agora which was located spatially or in a more modern way the town hall or the houses of associations or unions. Besides the fact that these places of public debate would be deserted, political philosophers will associate other impoverishments with them. The democratic debate can become a simple game for Geeks who confuse the means (being on the web, having an avatar) and the goal, which is the debate of ideas. This can give rise to the practice of "name and shame" with the totalitarian tendencies that can accompany it as we have seen on the occasion of the yellow vests movement in the 'Finkelkraut affair' or with the attacks on the homes of deputies of the Republic. All this of course makes it all the more useful for a time office to have a fine tool for analysing transformations in temporality. This tool exists; it is about the time budget that we will now present, adapting it to our purpose.

\section{THE TIME BUDGET, A USEFUL EVALUATION TOOL FOR TIME OFFICES}

The first survey focusing specifically on the time budget of city dwellers dates from the 1970s (Lemel, 1972). It will be followed by surveys of transport time budgets which allow urban planning by taking into account the collective transport development needs linked to urban sprawl (Raux, 2010). The United Nations organization, on the other hand, uses this tool to highlight development gaps between countries. This type of survey served as a basis for the 
implementation of temporal policies by taking into account the distribution of different times between city dwellers and others and between men and women. They have not yet been used to the analysis of the effects on the liveable of the second type of approach which aims at the recomposition of temporalities in space, apart perhaps with regard to the development of free time devoted to leisure which is a personal time. The methodological problems associated with this type of survey are known. By approaching them we will show how to adapt the time-budget method to make it a useful tool for the time office. This involves specifying the objectives of the survey, the sample, the methods of organization of the survey, the type of questions asked the type of nomenclature of activities used in connection with the type of temporality. For now, we will set aside questions of coding and method of data analysis that we may ask ourselves once the collection is complete. We will use the statistical guide published by the United Nations in 2007, as well as the French National Institute of Statistics and Economic Studies (INSEE) ten-year survey method, to obtain elements of the methodology.

The success of "smart-cities" begins with the development of tools that we will qualify as "smart". They will aim at the temporal regulation of the lives of individuals and the way in which they participate in the establishment of a digital democracy. To know if they improve the temporal equation or impoverish it as we have shown in the second part we will have to see how they act to reduce the time pressure of work and / or territorial time on personal time. This will avoid setting aside this time. We will also assess their contribution to heterotopia. This is important since time can neither be saved nor increased, on the other hand we can do several things in the same place and in addition "at home" we are then able to reduce the pressure of working time or the uselessness of certain territorial times. To know if they improve digital democracy it will be necessary to measure the time spent using these tools to formulate ideas or opinions thanks to them. It will be necessary to have indications on the motivations associated with this time whatever the field.

They are planning tools for a country like France where this tradition exists, or a development planning tool for the United Nations organization. We will use it for urban planning from a bottom up perspective as we have indicated. It will be a tool for the office of times to assess the ex-ante impact of a public decision to develop smart infrastructure. We mentioned in the introduction the need to use it for an integrated impact assessment before any public decision. This will be used to monitor the development of cities that have chosen this model, in particular because there is a systemic relationship between the tools that will allow their effects to change significantly. Nothing prevents, within the framework of an exchange of good practices, to also carry out a comparison between two cities of different size and / or in different countries, in particular to take into account the contextual elements of the development of "smart cities".

The United Nations (UN) and INSEE surveys are highly time-lagged because they are based on a large sample that best represents the population of a country. The discrepancy is explained by their heaviness but also by the fact that they want to take into account major trends in the evolution of the distribution of time between working time and other times and to highlight the evolutions related to the increase in the female activity rate on the distribution of domestic activities within a household. The time office, on the other hand, will have much more spatially localized and much more regular surveys. For the impact study that is done before making the public decision, we can enter into an UrbanLab procedure to test the use of a smart tool. We can also use a control panel that will be mobilized for each development project of a smart action. To ensure policy monitoring over time, surveys will need to be 
carried out with a representative sample of citizens. The annual framework is suitable when the action is linked to the budget vote, but you can also choose the framework of the time horizon of the project concerned.

To carry out surveys allowing the comparison of countries and / or lifestyles, elements relating to contextual variables must be integrated into the survey process. Figure 1 shows all of these variables.

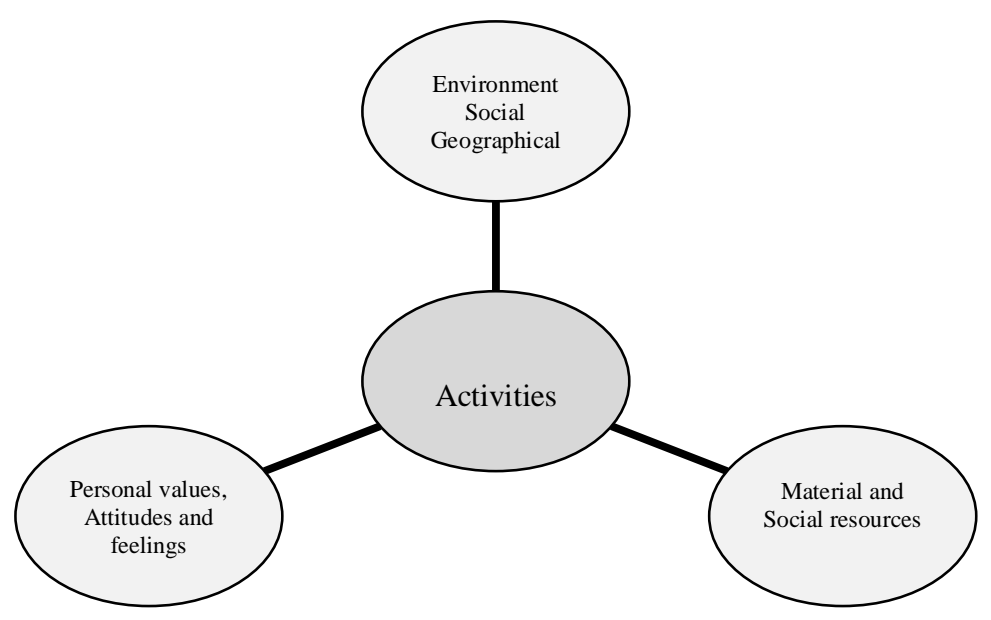

Figure 1. The contextual variables influencing the survey

Source: (United Nations, 2007)

Among the contextual elements, we find those which will more or less influence the vision of the uses that we make of our time (INSEE, 2011). Not taking them into account is taking the methodological risk of de-contextualization (Ramos, 2008).

The elements linked to the spatial and political organization of territories are decisive for the temporal regulation of public services by smart tools (Bauby, 2011; Duez, 2019). They are also by necessity for the advent of a digital democracy. These elements are invariable (United Nations, 2007). Some countries, for example, are more decentralized than others, they easily develop public-private partnerships or they do not have the same urban framework. It will be up to those who analyse the time budgets in the office to reintroduce some elements ex-post. Interpretation cannot indeed be done in absolute terms when studying the time budgets of a country or a city.

There are also subjective elements like feelings, values that influence the perception of time. In addition, certain events will exceptionally make this or that weather less appreciated. To assess these subjective elements, INSEE adds in these surveys a rating of the moment between -3 and +3 for each period of 10 minutes and the assessment of the day by a rating from 1 to 10 . The fact of placing a rating facilitates undoubtedly the work of codifying the responses but poses methodological problems. The cardinal ranking of preferences is always more difficult for respondents to perform, especially since the scoring below Zero to three is not natural even for a panel to which everything has been explained to them at the start. A Likert scale is more suited to this type of ranking if it asks respondents to say whether they are not at all satisfied, just satisfied, or very satisfied. 
In our survey, the risk of de-contextualization is not quite the same. Subjectivity can be introduced in the appreciation of the impoverishment of the temporal equation due to an ethical deficit as we have shown in the second part. Those who are victims will not see the marginalization of personal time as an impoverishment but as enrichment of the equation or they will be indifferent to what it can bring them. In risk theory we will say that they have negative distortions in relation to the dangers incurred since they underestimate the risks. This is the attitude that seems most likely to us. In doing so, we might think that we are the victim of the Tower of Babel syndrome by being wary of any transcendent vision of the city (Ascher, 1995). On the contrary, we took this risk of "de-contextualization" because it seemed necessary to us in a context of rapid development of the smart city and of almost absolute confidence in the process. We do believe that "there are phenomena that cannot be addressed without intensifying and magnifying them. Phenomena which, escaping the naked eye, place us in the following alternative: "Or exaggeration or renunciation of knowledge" (Anders, 2002). We will therefore eliminate the survey of the perception of subjectivity linked to a rating to give more importance to what when events could in the short term or long-term result from a more or less bad advising attitude and which influences the perception time. We will count for what they mean, but we will not analyse at the end of the survey the eccentric responses or non-responses of those for whom this constitutes a way of expressing their subjectivity. The questions asked of the respondents will relate to the confidence placed in smart tools, given the implicit vision of the future that the respondents will reveal by answering it (Merleau-Ponty, 1955). These questions are very important because they are linked with the ethic problem to appreciate the effects on the smart city on the liveable and may be asked before the survey is carried out in the case of an UrbanLab.

Neither should we forget to introduce into the contextual elements the link with the economic and social resources which cross all societies (Busch M.-C. , 1975). The UN and INSEE surveys include them in the form of questions before the survey is carried out. We propose to integrate some of them either upstream for the UrbanLab, which will also constitute an essential element in the constitution of the panel or downstream for monitoring. Let us specify those which for the purposes of the survey will interest us. The social division of labour by gender of temporalities does not interest us since it pursues an objective of sustainable development that is not ours in this article. It may be interesting to ask a question about the profession without evoking the classification into socio-professional categories because certain professions benefit from a different esteem from a virtual status associated with their role in society (Boudon \& Bourricaud, 1982). However, this will necessarily influence the conception of temporality linked to work. In return, the results analysis must take into account the evolution of the esteem of a profession over time. Moreover, this question can be associated with economic resources and the culture associated with them. However, this question is essential for access to smart tools as we saw in the second part. Age is also an important contextual variable, because all other things being equal, it conditions the ability to use tools and necessarily conditions their impact on temporality. Not taking it into account could result in significant discrepancies between budget-time that we would be difficult to interpret without this variable.

The question of activities is of course decisive for the time office. It is about analysing the influence of the recomposition of time associated with activities from the perspective of a temporal ecology emphasizing personal time. This involves analysing the effects of heterotopia, which consists of being able to perform in the same place several activities corresponding to different temporalities. To answer the first problem, INSEE lets respondents indicate the nature of the activity but asks them in a second survey to specify the "for whom" 
these activities are carried out. The problem is that the nomenclatures used are extremely complex. For example, there are no less than 7 community activities selected by the UN (Annex 5 of the (United Nations, 2007). While the INSEE nomenclature contains no less than 170 headings in its most detailed version. As for the problem of heterotopia, INSEE and the UN propose to solve it by asking respondents to distinguish between a main activity and a secondary activity. For example, you can watch TV and iron at the same time or phone your wife at her workplace to tell her that you love her.

On the other hand, the time office would need to know immediately how the two forms of spatial and temporal relations will play on the temporal equation and indirectly on democracy. To simplify the respondents' answers, we can ask them to indicate the time - even very short times - spent in the activities by checking the place where they took place. As the number of activities is very large, the respondent will be asked to include the activity if possible by adding a verb if necessary to make them understood. We will of course have to rely on the sincerity of the respondents for the answers of the type of crossword puzzles at work, but the regularity of the survey should allow correcting the temptations not to reveal the places in which they do things. A special place will of course be attributed to the use of smart tools activity. If the office wants to test a tool or several tools for certain uses, it will be necessary to indicate to the respondent for which activities they could use them and the place (the nomenclature is presented in Appendix 1). We can respond by simply putting the code to go faster. If the office wants to follow a device, it will indicate for which activities it will use a particular tool and in which places. We will avoid nomenclatures that are too technological smart-grids or public Wi-Fi-linear that the respondents do not understand.

Finally, the time-budget method assumes that respondents are given a notebook that is more or less open in terms of time, since they will fill in every day for a month. Appendix 2 contains all of the elements mentioned above. It will be distributed while avoiding vacation times which will do nothing in terms of the regulation of temporality. Its distribution will be preceded by a "guinea pig" exercise. At the same time, we will distribute a survey guide to respondents on how to complete the log. It can be actively open we did not choose this layout and we have explained why. It can be closed in terms of times like the UN does, considering that respondents will not have the necessary discipline and that the assessment of time can be relative. She suggests spacing out the responses by 10 minutes to be able to more objectively appreciate the changes in temporalities. We prefer an open temporality over a 24-hour day including rest time related to sleep. The respondent will estimate the time he devotes himself because this will allow the re-introduction of the subjectivity linked to time pressure. Because we have planned more regular surveys and this will allow us anyway to identify a trend useful for the time office failing to have an exact measure of the time that we will not have in the diaries either of closed times. Because it will facilitate the work of respondents who will not be discouraged in an assessment of the difficult time to do 10 by 10 or who will in some cases answer anything to fill out the notebook? They will also be able to respond all the more easily at the end of the day as it is structured and does not impose this temporal detail / ultimately we can reserve the closed intervals by offering a typical day notebook modelled on the classical temporalities for urban-lab type surveys.

\section{CONCLUSIONS}

Urban planning is evolving more and more towards sustainability. Time-based policies are most often implemented on an experimental basis in certain cities to pursue different objectives. They aim to reduce territorial gender inequalities, notably by ensuring better 
regulation of public services. They aim to make the urban world more liveable by recomposing space based on a change in the management of territorial temporalities. The development of "smart cities" is one of the new approaches that could be integrated into temporal policies to pursue the two objectives but also to develop territorial intelligence and democracy.

In a context of post-new-public-management and the absence of legal standards for liveable planning, it is important to have a tool for evaluating these policies. It will be necessary in particular to legitimize the action of the time office, which will have to coordinate all actions in terms of time policy and ensure follow-up. The tool we propose to use is the time budget. It will of course have to be adapted in order to keep in mind that it must be able to highlight the enrichment of the temporal equation of urbanites and not its impoverishment. In particular, it should make it possible to measure the effects of the recompositions of the different temporalities between them on the liveable. It will not of course be the only tool if we start from the principle that impoverishment has effects on the existential affirmation of urbanites. Action on the temporal equation can effectively result in a hardening of temporalities which will have effects on the rise of suicides, the number of drug addicts, etc. On the other hand, spatial planning policies are not sufficient on their own. They are likely to limit the negative effects of the labour process on urban life, but for them to be truly effective they would have to serve another economic ethic.

To give more concreteness to our approach, we are proposing to create an "urban lab" which will allow the method to be tested in two cities of different size and nationality. We will take as a reference an average French city above the 20,000 hour threshold proposed by the Hervé report to create a time office and a European capital, in this case Bucharest in Romania. We will use the time-budget method to study the impact of the implementation of "smart" tools within time policies in these two cities. This comparative analysis will be carried out within the framework of a thesis which will inevitably be able to highlight the differences in impact associated of course with the size of the city, its sprawl and its population, but also the differences that can be associated with the general context of each country. These differences may relate to the existence of different legal standards in terms of the regulation of public services and / or regional planning or even in terms of spatial organization, particularly with regard to the state of progress of decentralization and differences in urban structure between the two countries.

\section{REFERENCES}

Anders, G. (2002). L'obsolescence de l'homme: Sur l'âme à l'époque de la deuxième révolution industrielle. Paris: Editions de l'Encyclopédie des Nuisances.

Anders, G. (2011). 'obsolescence de l'homme. Tome 2. Sur la destruction de la vie à l'époque de la troisième révolution industrielle. Paris: Fario.

Arendt, H. (1983). Condition de l'homme moderne. Paris: Calman-Lévy.

Arnsperger, C. (2010). Changer d'existence économique, Enjeux anthropologiques de la transition du capitalisme au post-capitalisme. Revue d'éthique et de théologie morale, 2010/1(258), 23-50.

Ascher, F. (1995). Métapolis ou l'avenir des villes. Paris: Éditions Odile Jacob.

Ascher, F. (2003). L'ambition moderne de maîtrise individuelle des espaces-temps: outils et enjeux. În F. Ascher, \& F. Godard, Modernité: la nouvelle carte du temps (pg. 17-28). EDITIONS DE L'AUBE .

Augé, M. (1992). Non-lieux. Introduction à une anthropologie de la surmodernité. Paris: La Librairie du XXIe siècle. Seuil.

Bauby, P. (2011). L'européanisation des services publics. Paris: Presses de Sciences Po. 
Berque, A. (2009). Ecoumène. Paris: Belin, (1ère édition 1987).

Beyer, C., \& Royoux, D. (2015). L'aménagement temporel territorial : repenser les territoires en conjuguant espace et rythmes. Métropoles(17), 1-16.

Boltanski, L., \& Chiapello, È. (1999). Le nouvel esprit du capitalisme. Paris: Gallimard, Collection Tel $\left(n^{\circ} 380\right)$.

Boudon, R., \& Bourricaud, F. (1982). Dictionnaire critique de la sociologie. Paris: PUF.

Boulin, J.-Y. (2003). Les temps de la ville. Revue Projet, 2003/1(273), 64-72.

Boulin, J.-Y., \& Mückenberger, U. (2002). La Ville à mille temps. La Tour-d'Aigues: Éditions de l'Aube.

Burbage, F. (2013). Philosophie du développement durable. Enjeux critiques. Paris: PUF. Philosophies.

Busch, M.-C. (1975). La sociologie du temps libre. Paris: Mouton.

Choay, F. (2006). Pour une anthropologie de l'espace. Paris: Éditeur SEUIL, Collection La couleur des idées.

Chopplet, M. (2018). Smart City : quelle intelligence pour quelle action ? Les concepts de John Dewey, scalpels de la ville intelligente. Quaderni, 71-86.

de Montbrial, T. (1985). La revanche de l'histoire. Paris: Julliard.

Di Méo, G. (1991). L'Homme, la Société, l'Espace. Paris: Anthropos.

Dommergues, P., \& Delfour, C. (2001). L'émergence de politiques publiques temporelles en Franceet en Europe (extraits de: Les temps de la ville et les modes de vie - Quelles perspectives d'actions ?, Collections du Certu, Débats $\mathrm{N}^{\circ} 34$-Septembre 200). Le temps de la ville, 75-87.

Douay, N. (. (2013). La planification urbaine française : théories, normes juridiques et défis pour la pratique (French urban planning: theories, legal norms and challenges for practice). L'Information géographique (The geographical information), vol. 77(3), 45-70.

Duez, P. (2019). New public Management and territories scales. Proceedings of The 14th edition of International Management Conference (p. 13). Bucharest, 4-6 november 2019: ASE.

Dumouchel, P., \& Dupuy, J. P. (1979). L'enfer des choses: René Girard et la logique de l'économie. Paris: Seuil.

Dupuy, F. (2001). Anthropologie économique. Paris: Armand Colin.

Eveno, E. (2018). La Ville intelligente : objet au cœur de nombreuses controverses. Quaderni, 29-41.

Ferrier, J.-P. (1998). Le contrat géographique ou l'habitation durable des territoires. Lausanne: Éditions Payot.

Forget, P., \& Polycarpe, G. (1990). L'Homme Machinal. Technique Et Progrès : Anatomie D'Une Trahison. Paris: Syros-Alternatives.

Freitag, M. (2002). L'oubli de la société. Pour une théorie critique de la postmodernité. Rennes: Presses Universitaires de Rennes, coll. « Le sens social ».

Furtado, C. (1987). La crise économique contemporaine . Revue Tiers Monde, 877-885.

Gauchet, M. (1998). Essai de psychologie contemporaine. Le Débat, 1998/2 (n 99), 164-181.

Giarini, O. (1981). Dialogue sur la richesse et le bien-être. Rapport au Club de Rome. Paris: Economica.

Gorz, A. (1997). Misères du présent, richesse du possible. Paris: Éditions Galilée.

Gravari-Barbas, M., \& Violier, P. (. (2003). Lieux de culture, culture des lieux. Production(s) culturelle(s) locale(s) et émergence des lieux : dynamiques, acteurs, enjeux. Rennes: Presses universitaires de Rennes.

Grossin, W. (1996). Pour une science des temps. Introduction à l 'écologie temporelle. Toulouse: Éditions Octares.

Guibert-Sledziewski, É. (1988). Développement et “production de l'être humain " chez les Idéologues . În O. Bloch, Entre forme et histoire. La formation de la notion de développement a l'âge classique: actes des journées d'études organisées à la Sorbonne les 20 et 27 janvier 1985, 26 avril et 7 juin 1986. Paris: Méridiens-Klincksieck.

Hammerschmid, G., Andrews, R., \& Mostafa, A. M. (2019). Effets des réformes inspirées de la nouvelle gestion publique en Europe : résultats d'une enquête réalisée auprès de hauts responsables de 20 pays. Revue Internationale des Sciences Administratives, Volume: 85, 411 431. 
Henriot, C., Douay, N., Granier, B., Languillon-Aussel, R., \& Leprêtre, N. (2018). Perspectives asiatiques sur les Smart Cities. Flux, 1-8.

Hottois, G. (1990). Le progrès. De la temporalité historico-anthropothéologique et. Revue Laval théologique et philosophique, Volume 46, numéro 3, 337-351.

INSEE. (2011). Les moments agréables de la vie quotidienne. Une question d'activités mais aussi de contexte. Paris: INSEE PREMIÈRE.

Lacour, C., Delamarre, A., \& Thoin, M. (2008). Quarante ans d'aménagement du territoire (Forty years of regional planning). Paris: LA DOCUMENTATION FRANCAISE.

Lemel, Y. (1972). Éléments sur les budgets-temps des citadins. Economie et Statistique, 3-15.

Lipovetsky, G. (2004). Les temps hypermodernes. Le Philosophoire, 22(1), 184-188.

Lucchini, F. (2015). Temporalités et rythmes urbains : les interprétations géographiques du temps et les espaces urbains. L'Information géographique, 2015/2 (Vol. 79), 28-40.

Mallet, S. (2014). Vie urbaine et temps communs. Esprit, décembre(12), 36-45.

Marchand, J.-S., \& Brunet, M. (2019). L'émergence des initiatives post-NMP : l'évaluation d'impact intégrée comme un outil hybride d'aide à la prise de décision. International Review of Administrative Sciences, 85(2), 331-347.

Merleau-Ponty, M.-J.-J. (1955). Les aventures de la dialectique. Paris: Gallimard.

Micoud, A. (2005). Patrimonialisation: Redire ce qui nous relie? În C. B. Barrère, M. Nieddu, \& F.-D. Vivien, Réinventer le patrimoine. De la culture à l'économie, une nouvelle pensée du patrimoine? (pg. 81-96). Paris: Editions L'Harmattan.

November, V. (2002). Les territoires du risque. Lausanne: P.I.E. Peter Lang SA.

Planterose, P. (2014). Télétravail : travaillez en vivant mieux. Paris: Eyrolles.

Polanyi, K. (1988). La Grande Transformation. Aux origines politiques et économiques de notre temps. Paris: Gallimard, Collection Bibliothèque des Sciences humaines.

Ramos, J.-M. (2008). Aperçu de la recherche sur le temps et les temporalités en psychologie sociale.Limites et avancées (Research on time and temporalities in social psychology : limits and advances). Temporalités, https://journals.openedition.org/temporalites/105.

Raux, C. (2010). La croissance des budgets-temps de transport. Approfondissement. Rapport. Paris: Ministère de l'Ecologie, de l'Energie, du Développement Durable et de la Mer.

Rifkin, J. (2000). L'âge de l'accès. La nouvelle culture du capitalisme. Paris: La Découverte.

Rochefort, R. (1997). Le Consommateur entrepreneur. Les nouveaux modes de vie. Paris: Editions Odile Jacob.

Rosa, H. (2010). Accélération. Une critique sociale du temps. Paris: La Découverte, coll. «Théorie critique $»$.

Royoux, D. (2017). Les politiques publiques locales à l'épreuve des disjonctions temporelles. Multitudes, 61-69.

Testart, A. (2012). Avant l'histoire. L'évolution des sociétés, de Lascaux à Carnac. Paris: Gallimard, Collection Bibliothèque des Sciences humaines.

United Nations. (2007). Guide des statistiques du budget-temps: mesures du travail rémunéré et non rémunéré. New York: United Nations Publication.

Vergely, B. (2015). La tentation de l'homme-Dieu. Paris: Le Passeur Editeur.

Zarifian, P. (2003). Le temps du travail, le temps-devenir face au temps spatialisé. În F. Ascher, \& F. Godard, MODERNITE: LA NOUVELLE CARTE DU TEMPS (pg. 85-100). Paris: EDITIONS DE L'AUBE. 